\title{
13. FISSION TRACK ANALYSIS OF DETRITAL APATITES FROM SITES 859, 860, AND 862, CHILE TRIPLE JUNCTION
}

\author{
Annette D. George ${ }^{2}$ and Kerry A. Hegarty ${ }^{3}$
}

\begin{abstract}
Fission track analysis of detrital apatite grains recovered from sediment samples of upper Pliocene to Quaternary age from the Chile Triple Junction (Sites 859, 860, and 862), shows that the apparent ages of individual grains are older than the stratigraphic ages. The apatite fission track data indicate that there has been no significant postdepositional heating (i.e., maximum paleotemperatures have never exceeded $\sim 60^{\circ} \mathrm{C}$ ). The apatite grains, therefore, derive their fission track characteristics from the source area. The mineral assemblages are similar in all samples and indicate that this source area was dominated by crystalline basement and a volcanic terrain. The track-length distributions characterized by relatively long means (13-14 $\mu \mathrm{m})$ are a significant feature of the fission track data, given that the apatite grains were eroded from mixed sources of a known broad age range. These data record moderately rapid cooling through $\sim 110^{\circ} \mathrm{C}$, which we attribute to moderately rapid uplift and erosion of the source area, followed by transportation and deposition of the sediment.

Two distinct age populations are recognized in the combined samples from each of the three sites. The younger population is represented by a fission track age of $\sim 7 \pm 2 \mathrm{Ma}$, whereas the older population gives an age of $\sim 25 \pm 5 \mathrm{Ma}$. The younger age group is interpreted as revealing the time of moderately rapid cooling, produced by uplift and erosion of the source area. Recognition of this late Miocene ( $\sim 7 \mathrm{Ma})$ event in the fission track data coincides with several major processes, including magmatism and tectonism, which have been documented already in the area. Erosion of the source ( $\operatorname{arc}-$ forearc) region at this time is most likely a direct result of tectonic uplift caused by collision and subduction of one or two segments of the Chile Ridge. The older age ( 25 $\mathrm{Ma}$ ) identified in the fission track data records a discrete cooling event which we interpret as denudation and/or deformation of the forearc-arc region as a consequence of oblique convergence at the Chile margin.
\end{abstract}

\section{INTRODUCTION}

Collision of the Chile Ridge spreading center and the Chile Trench provided the thematic focus for Leg 141 of the Ocean Drilling Program. The Chile Triple Junction is presently located at $45^{\circ} 40^{\prime} \mathrm{S}-47^{\circ} \mathrm{S}$ off the coast of southern Chile (Fig. 1), and previous marine geophysical studies indicate that the triple junction has migrated northward from the site of initial collision at approximately $15 \mathrm{Ma}$ (Herron et al., 1981; Cande et al., 1987).

Various tectonic and geological processes have been inferred in the forearc and arc region as a direct consequence of ridge subduction, including rapid vertical movements, elevated geothermal gradients and anomalous near-trench magmatism (DeLong and Fox, 1977; DeLong et al., 1979; Marshak and Karig, 1977; Forsythe et al., 1986). Recognition of these effects in the stratigraphic record was one of the primary objectives of Leg 141. Fission track analysis is an appropriate technique to investigate these effects because it utilizes the sensitivity of fission tracks in uranium-bearing minerals at low temperatures to determine the timing of cooling (e.g., uplift and erosion) events. A fission track study was undertaken using detrital apatites from sediment samples from three of the five drill sites: 859 and 860 in the collision zone, and site 862 approximately $25 \mathrm{~km}$ south on the Taitao Ridge (Fig. 1). Fission track ages and track-length distributions from these samples are interpreted with respect to the tectonic evolution of the forearc region and the postdepositional thermal history of the sediments.

\footnotetext{
'Lewis, S.D., Behrmann, J.H., Musgrave, R.J., and Cande, S.C. (Eds.), 1995. Proc. ODP, Sci. Results, 141: College Station, TX (Ocean Drilling Program).

${ }^{2}$ School of Earth Sciences, The University of Melbourne, Parkville, Victoria 3052 Australia. (Present address: Department of Geology. The University of Western Australia, Nedlands, W.A. 6009, Australia.)

${ }^{3}$ Geotrack International, P.O. Box 4120 , Melbourne University, Victoria 3052 Australia.
}

\section{APATITE FISSION TRACK ANALYSIS Background}

Apatite fission track analysis (AFTA) of detrital grains in sediments and sedimentary rocks is a powerful method for interpreting and modeling the thermal histories of sedimentary basin-fills. The observation that fission tracks in apatite anneal at temperatures below $\sim 110^{\circ} \mathrm{C}$ over geological time makes them particularly useful in petroleum exploration and basin modeling (e.g., Naeser, 1981; Gleadow et al., 1983; Gleadow et al., 1986). In sediments that lack a significant postdepositional overprint (sediments that have not been heated significantly since deposition, i.e., less than $\sim 60^{\circ} \mathrm{C}$ ), fission track analysis may be used to establish source terrain cooling histories. The fission track age provides constraints on the time elapsed since the source rocks cooled through about $110^{\circ} \mathrm{C}$, and the track-length distributions can be used to determine the thermal history which can be used to study the history of uplift and erosion (e.g., Agar et al., 1989; Kamp et al., 1989; Corrigan and Crowley, 1990; Arne, 1992). Furthermore, fission track ages may help define the source terrain(s) from which the sediments were eroded (e.g., Gleadow et al., 1983; Duddy et al., 1984; Hurford and Carter, 1991).

Estimates of maximum paleotemperature and time of maximum temperature are derived from AFTA data using well-established modeling techniques. The basis of the AFTA technique, principles of interpretation, and the kinetics of the annealing model describing fission track behavior used in this study have been described in a series of papers (Gleadow et al., 1983; Green et al., 1986; Laslett et al., 1982; Laslett et al., 1987; Duddy et al., 1988; Green et al., 1989).

\section{Sample Preparation and Analytical Procedures}

Samples of 10 to $40 \mathrm{~cm}^{3}$ were taken from sandy intervals of turbidites in cores from Sites 859,860 , and 862 (Table 1). Unconsolidated core samples were disaggregated by stirring in $0.1 \%$ Calgon solution in an ultrasonic tank, then wet sieved through a $63-\mu \mathrm{m}$ mesh to recover the sand fractions. The two cemented samples were crushed to sand 
Table 1. Core samples from Leg 141 sites used in fission track analysis.

\begin{tabular}{|c|c|c|c|c|c|}
\hline $\begin{array}{l}\text { Sample } \\
\text { number" }\end{array}$ & Hole & $\begin{array}{l}\text { Core, section, } \\
\text { interval }(\mathrm{cm})\end{array}$ & $\begin{array}{l}\text { Depth } \\
\text { (mbsf) }\end{array}$ & $\begin{array}{c}\text { Depositional } \\
\text { age }^{\mathrm{b}}\end{array}$ & Sediment/rock type \\
\hline RD $30-6$ & $859 \mathrm{~B}$ & $17 R-1.27-29$ & 264.57 & late Pliocene & Carbonate-cemented muddy sandstone \\
\hline RD 30-5 & $859 \mathrm{~B}$ & $17 R-4,67-69$ & 269.47 & late Pliocene & Carbonate-cemented muddy sandstone \\
\hline RD30-1 & $860 \mathrm{~B}$ & $5 \mathrm{H}-7.60-66$ & 39.50 & late Pliocene & Silty sand \\
\hline RD $30-2$ & $860 \mathrm{~B}$ & $6 \mathrm{H}-6,57-59$ & 47.47 & late Pliocene & Fine-medium sand \\
\hline RD $30-3$ & $862 \mathrm{~A}$ & $1 \mathrm{H}-2.42-45$ & 1.92 & Neogene $(2 \text { m.y. })^{c}$ & Silty fine sand \\
\hline \multirow[t]{5}{*}{ RD $30-4^{\prime \prime}$} & $862 \mathrm{~A}$ & $1 \mathrm{H}-3,13-14$ & 3.13 & Neogene ( 2 m.y.) & Silty fine sand \\
\hline & & $1 \mathrm{H}-3.125-127$ & 4.25 & Neogene ( 2 m.y.) & Silty fine sand \\
\hline & & $2 \mathrm{H}-3,94-97$ & 9.34 & Neogene ( 2 m.y.) & Muddy fine-medium sand \\
\hline & & $2 \mathrm{H}-5,69-72$ & 12.09 & Neogene ( 2 m.y.) & Muddy fine-medium sand \\
\hline & & $2 \mathrm{H}-7,52-55$ & 14.92 & Neogene ( 2 m.y.) & Muddy fine-medium sand \\
\hline
\end{tabular}

"Sample numbers assigned by Geotrack International.

h Biostratigraphic assignment.

- Deeper parts of hole (not sampled here) are possibly late Pliocene.

$\triangle$ RD 30-4 is a composite of the sand fractions from the five core samples listed; each had low individual sand components.

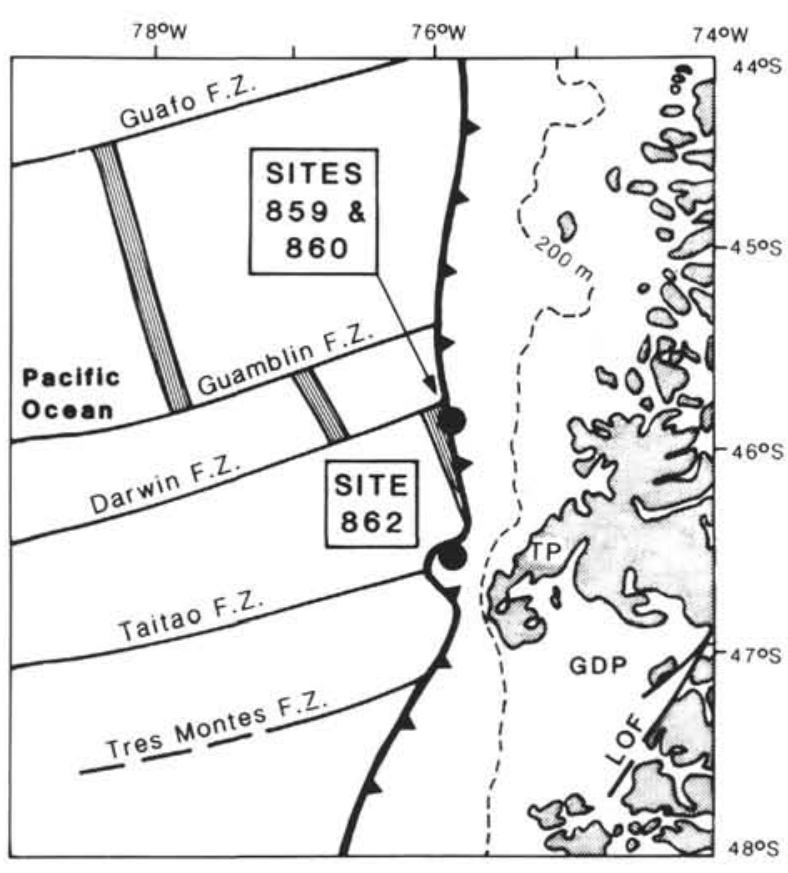

Figure 1. Location of the Leg 141 sites at the southern Chile margin (shaded) in the vicinity of the triple junction defined by collision of the Chile Ridge spreading center and associated transforms with the Chile Trench (heavy line with teeth on upper plate) $. \mathrm{TP}=$ Taitao Peninsula $; \mathrm{GDP}=$ Golfo de Penas Basin; $\mathrm{LOF}=$ Liquine-Ofqui fault zone. The dashed line is the $200 \mathrm{~m}$ bathymetric contour.

size prior to washing. The apatite grains were separated from the coarse fractions by conventional heavy liquid and magnetic separation techniques, with all six samples providing excellent apatite yields.

The apatite separates were prepared for fission track analysis using the external detector method (Gleadow, 1981; Green, 1986) which enables apparent ages to be calculated on individual grains. Apatite grains were mounted in epoxy resin on glass slides and etched for 20 seconds in $5 \mathrm{~N} \mathrm{HNO}_{3}$ at $20^{\circ} \mathrm{C}$ to reveal the fossil tracks. Neutron irradiations were undertaken in the X-7 facility of the Australian Nuclear Science and Technology Organization's HIFAR reactor at Lucas Heights. Tracks in 20 grains per sample were counted, and ages calculated using the standard fission track age equation (Hurford and Green, 1982). Full analytical data for each sample are given in the Appendix, and a summary of results is presented in Table 2. Horizontal confined fission track lengths were measured in each sample and mean lengths are given in Table 2. All errors are given as $\pm 1 \sigma$ in the tables.

\section{PROVENANCE}

The sand fractions of each sample were examined in thin section to establish the nature of the source terrains. All samples are composed predominantly of quartz, with subordinate feldspar, brown volcanic glass, basic-intermediate volcanic lithic fragments, green amphibole, and plutonic-metamorphic lithic fragments. Biotite, epidote, zircon, and opaque oxides are common accessory minerals. The mineral assemblage indicates derivation from at least two sources, crystalline basement and a volcanic terrain. These sources are consistent with the known onshore geology in southern Chile which is dominated by the Late Jurassic to early Miocene Patagonian batholith, with Miocene volcanic centers and Quaternary calc-alkaline volcanoes (Forsythe and Nelson, 1985; Cande and Leslie, 1986). A pre-Late Jurassic metamorphic terrain is also exposed onshore in this area, and although no grains could be unequivocally assigned to this source, the possibility exists that it provided some of the sediment to the sample sites. Thus, the source area is the arc-forearc region, including both the continental basement and superimposed magmatic arc rocks.

\section{RESULTS AND INTERPRETATIONS}

The AFTA data generated for this study are of very high quality because of the excellent apatite yields, generally moderate to high uranium contents, and low present-day sample temperatures. Two AFTA samples from each of the three sites provided six samples which were initially processed independently.

AFTA parameters (single-grain ages and confined track-length measurements) were determined for each of the six samples (Figs. 2 and 3; Table 2). Calculated fission track ages for each sample are quoted for comparison in Table 2, but are not used in the interpretation of thermal history, as the single grain ages in all but one sample (RD30-6) do not represent a single population of ages, and the spread of single grain ages must be considered.

\section{Postdepositional Thermal History}

At an error of $\pm 2 \sigma$, none of the fission track ages of individual apatite grains is significantly younger than the corresponding stratigraphic age of any of the samples (Appendix; Table 2). These age data, together with track-length modeling, show that maximum postdepositional paleotemperatures could not have exceeded $\sim 60^{\circ} \mathrm{C}$, and provide clear evidence that there has been little to no postdepositional heating.

\section{Evidence for Predepositional Heating/Cooling}

One of the most striking features of the data is the relatively long mean length characterizing the distribution of horizontal confined 
Hole 859B
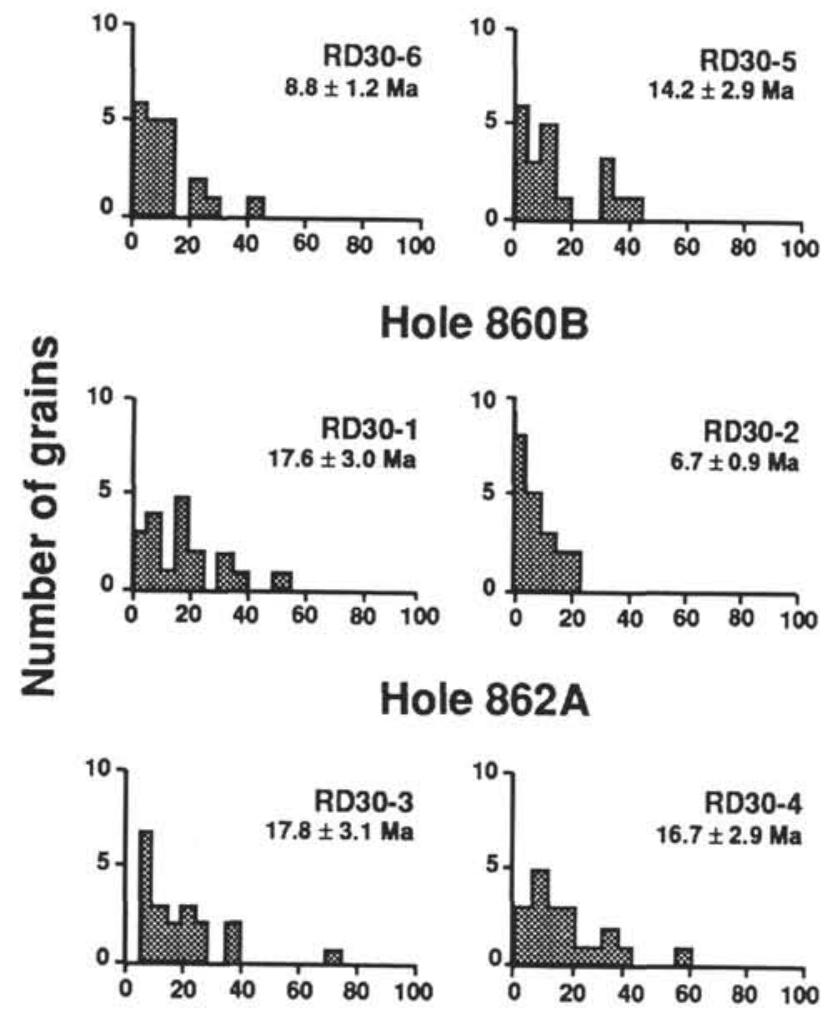

Hole 862A

Fission track age (Ma)

Figure 2. Histograms of single grain fission track ages for samples from Leg 141 holes.

track measurements in each sample (in the range 13.3 to $14.2 \mu \mathrm{m}$, Table 2). The long mean lengths suggest that most of the tracks have experienced only a small degree of annealing since track formation, and together with the age data, provide further support for little postdepositional heating of the sediment. We interpret the tracklength data to indicate that most of the fission tracks formed after moderately rapid cooling (i.e., $>20^{\circ} \mathrm{C} / \mathrm{Ma}$ ) of the source rocks from paleotemperatures of $\sim 110^{\circ} \mathrm{C}$ or more. Had the source cooled slowly, (i.e., $<10^{\circ} \mathrm{C} / \mathrm{Ma}$ ), the length distribution would contain a shorter component of tracks, in the range 7-12 $\mu \mathrm{m}$ (e.g., Gleadow et al., 1986), which represent those tracks that were partially annealed during the slow cooling event.

It is clear from petrographic work, coupled with the known onshore geology, that the sediments (including the apatite grains) were derived from more than one source. The source rocks are dominantly plutonic and volcanic types, and vary in age from Late Jurassic to Quaternary, possibly including a pre-Late Jurassic metasedimentary terrain. The track-length distributions characterized by relatively long means is a significant feature of the AFTA data, particularly given that the apatite grains were eroded from mixed sources of a broad age range. The AFTA data provide evidence, therefore, that the source terrains cooled moderately quickly from paleotemperatures of at least $110^{\circ} \mathrm{C}$. Sediment input from the plutonic source (which is areally dominant onshore; e.g., Forsythe and Nelson, 1985) argues against derivation of all the apatite grains from rapidly cooled volcanic or high-level intrusive rocks. Furthermore, we attribute the moderately rapid cooling to uplift and erosion of the source area; however, a rapid decline in heat flow (e.g., cooling of the host rock after intrusion) cannot be ruled out. Following erosion, detrital apatite grains were transported and deposited at the drill sites.
Hole 859B
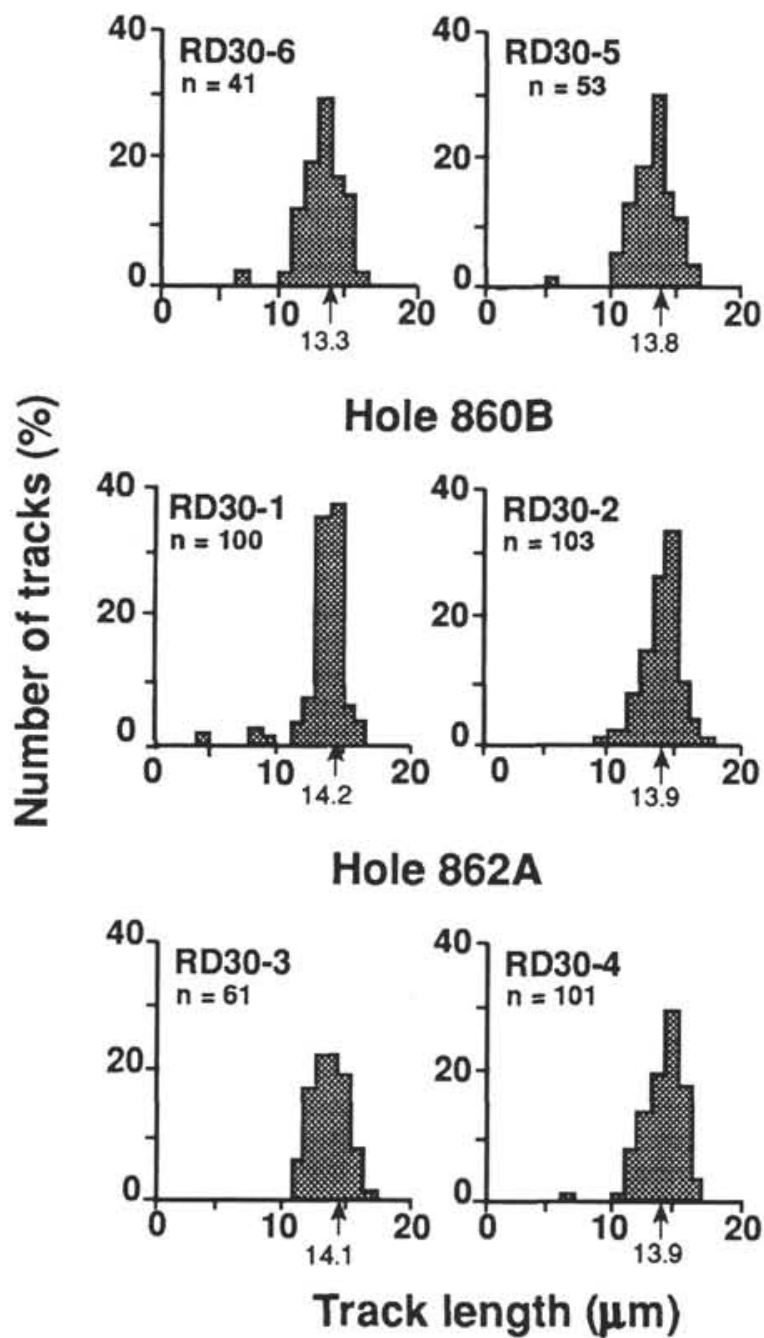

Figure 3. Histograms of confined track length measurements for samples from Leg 141 holes. Number of tracks measured $(n)$ and mean track length in micrometers (arrows) is indicated for each sample.

\section{Timing of Thermal Events}

The two AFTA samples from each site are at present downhole temperatures that probably differ by only $1{ }^{\circ} \mathrm{C}$ because of the close sample spacing (Tables 1 and 2). For this reason, data generated from the two samples from each site were combined to improve the statistical analysis of the individual single grain ages. These combined samples consisting of 40 single grains are referred to by their drill site number (Table 3).

The chi-squared statistics for each composited sample show that there is significant variability in the single-grain ages within the samples (Table 3 ). To evaluate real differences in the single-grain ages, we make use of radial diagrams (Galbraith, 1988), which are useful for graphically representing trends in the single-grain age data (Fig. 4). All points on a straight line from the origin of each plot define a single value of fission track age, and the distance along the $x$-axis represents the corresponding precision of each single-grain determination. Therefore, precise individual grain ages fall to the right of the plot, which allows easy identification of young, precise grains. Although there is some scatter in the data (Fig. 4), broad trends can be seen in each of the three plots, particularly for younger ages for which more precise grains exist. 
Table 2. Summary of AFTA data for Leg 141 samples.

\begin{tabular}{|c|c|c|c|c|c|c|c|c|c|}
\hline $\begin{array}{l}\text { Sample } \\
\text { number }\end{array}$ & Hole & $\begin{array}{l}\text { Depth } \\
\text { (mbsf) }\end{array}$ & $\begin{array}{l}\text { Present } \\
\text { temp. } \\
\left({ }^{\circ} \mathrm{C}\right)\end{array}$ & $\begin{array}{l}\text { No. of } \\
\text { grains }\end{array}$ & $\begin{array}{l}\text { Stratigraphic } \\
\text { age }(\mathrm{Ma})^{c}\end{array}$ & $\begin{array}{c}\text { AFTA } \\
\text { age }(\mathrm{Ma})^{d}\end{array}$ & $\begin{array}{c}\text { Mean track } \\
\text { length }(\mathrm{mm})\end{array}$ & $\begin{array}{c}\text { Standard } \\
\text { deviation } \\
(\mu \mathrm{m})\end{array}$ & $\begin{array}{l}\text { No. of } \\
\text { confined } \\
\text { tracks } \\
\text { measured }\end{array}$ \\
\hline RD30-6 & $859 B$ & 264.57 & 29 & 20 & $3.4-1.6$ & $8.8 \pm 1.2$ & $1.3 .3 \pm 0.3$ & 1.8 & 41 \\
\hline RD $30-5$ & $859 \mathrm{~B}$ & 269.47 & 29 & 20 & $3.4-1.6$ & $14.2 \pm 2.9$ & $13.8 \pm 0.3$ & 1.7 & 53 \\
\hline RD30-1 & $860 \mathrm{~B}$ & 39.50 & 8 & 20 & $3.4-1.6$ & $17.6 \pm 3.0$ & $14.2 \pm 0.2$ & 1.8 & 100 \\
\hline RD30-2 & $860 \mathrm{~B}$ & 47.47 & 9 & 20 & $3.4-1.6$ & $6.7 \pm 0.9$ & $13.9 \pm 0.1$ & 1.3 & 103 \\
\hline RD $30-3$ & $862 \mathrm{~A}$ & 1.92 & 2 & 20 & $1.6-0 ?^{h}$ & $17.8 \pm 3.1$ & $14.1 \pm 0.2$ & 1.4 & 61 \\
\hline RD30-4 & $862 \mathrm{~A}$ & $14.92^{\mathrm{e}}$ & 3 & 20 & $1.6-0$ ? & $16.7 \pm 2.9$ & $13.9 \pm 0.2$ & 1,5 & 101 \\
\hline
\end{tabular}

${ }^{4}$ Present temperatures for Holes $859 \mathrm{~B}$ and $862 \mathrm{~A}$ calculated using a thermal gradient of $100^{\circ} \mathrm{C} / \mathrm{km}$ and a surface temperature of $2^{\circ} \mathrm{C}$. Hole $860 \mathrm{~B}$ calculated using a thermal gradient of $140^{\circ} \mathrm{C} / \mathrm{km}$ and surface temperature of $2^{\circ} \mathrm{C}$.

${ }^{b}$ Slight revision of stratigraphic ages or present temperatures will not affect our thermal history interpretation.

Uses the geologic time scale of Harland et al. (1990).

Central age used, except RD30-6. which uses the pooled age

"Maximum depth (see Table 1).

Table 3. AFTA data for composite samples.

\begin{tabular}{|c|c|c|c|c|}
\hline $\begin{array}{c}\text { Composite } \\
\text { sample }\end{array}$ & $\begin{array}{c}\text { Original } \\
\text { sample numbers } \\
\text { (strat. age. Ma) }\end{array}$ & $\begin{array}{c}\text { Age limits } \\
\text { of younger } \\
\text { population } \mathrm{Ma}^{a} \\
\text { (maximum } \\
\text { likefihood value) }\end{array}$ & $\begin{array}{c}\text { Age limits } \\
\text { of older } \\
\text { population } \mathrm{Ma}^{a} \\
\text { (maximum } \\
\text { likelihood value) }\end{array}$ & $\begin{array}{l}\text { P (chi-squared) } \\
\text { statistic }\end{array}$ \\
\hline 859 & $\begin{array}{c}\text { RD } 30-5 \text { and }-6 \\
(3.4-1.6)\end{array}$ & $\begin{array}{c}6.2-10.2 \\
(7.9)\end{array}$ & $\begin{array}{c}19.1-41.4 \\
(23.1)\end{array}$ & $<0.1 \%$ \\
\hline 860 & $\begin{array}{c}\text { RD } 30-1 \text { and }-2 \\
(3.4-1.6)\end{array}$ & $\begin{array}{c}4.2-7.3 \\
(5.6)\end{array}$ & $\begin{array}{c}15.4-26.7 \\
(20.2)\end{array}$ & $<0.1 \%$ \\
\hline 862 & $\begin{array}{c}\text { RD } 30-3 \text { and }-4 \\
(1.6-0 ?)\end{array}$ & $\begin{array}{c}7.3-11.2 \\
(9.1)\end{array}$ & $\begin{array}{c}24.3-38.1 \\
(30.5)\end{array}$ & $<0.1 \%$ \\
\hline
\end{tabular}

${ }^{4}$ Lower and upper $95 \%$ confidence limits.

${ }^{h}$ Definition of the $\mathrm{P}$ (chi-squared) statistic is given in the Appendix,

It is possible to quantify these broad trends by statistically analyzing for the separation of different age populations in each combined sample. Using the techniques of Galbraith (1988), we observed that the data from each sample show significant structure in individual grain ages, and two distinct age groups can be identified in each sample within $95 \%$ confidence limits (Table 3). At Site 859, the younger population gives a fission track age of $7.9 \mathrm{Ma}$ with lower and upper $95 \%$ confidence limits of 6.2 and $10.2 \mathrm{Ma}$, respectively. The lower and upper confidence limits of this population from Sites 860 and 862 are 4.2 to $7.3 \mathrm{Ma}$ and 7.3 to $11.2 \mathrm{Ma}$, respectively. There is remarkable consistency in the age of this population between samples, which is approximately $7 \pm 2 \mathrm{Ma}$ (Table 3 ). This pattern of single-grain ages, together with the track-length distributions, suggests that the samples (or grains in this case) cooled from paleotemperatures of $\sim 110^{\circ} \mathrm{C}$ or more near the time given by the age range of the youngest group (i.e., $\sim 7 \mathrm{Ma}$ ). Correcting the measured age for the modest amount of annealing recorded by the track lengths suggests that cooling may have commenced somewhat earlier, but not before $7.5 \mathrm{Ma}$ within the errors discussed above.

Similarly, lower and upper confidence limits were calculated for the older population identified in each sample (Table 3 ) and the ranges show an overlap at 24.3-26.7 Ma for the three samples. These grains may be richer in chlorine and therefore retain their fission tracks formed prior to the $\sim 7 \mathrm{Ma}$ event (see Green et al., 1985 for a discussion of the effects of chlorine content), or alternatively, the older grains were derived from a distinct terrain which did not experience cooling at $\sim 7 \mathrm{Ma}$. In conclusion, the AFTA data are compatible with a thermal model that consists of two events (at $\sim 7$ and $\sim 25 \mathrm{Ma}$ ) that are both associated with rapid cooling.

\section{IMPLICATIONS FOR TECTONIC EVOLUTION OF THE FOREARC AND ARC REGION}

The AFTA parameters are clearly dominated by inheritance: that is, they exhibit characteristics from their source rather than the post- depositional thermal environment. The shapes of the track-length distributions and long mean track lengths suggest that all samples cooled quickly through $\sim 110^{\circ} \mathrm{C}$, which we relate to uplift and erosion of the source area.

Two distinct age populations can be recognized in the upper Pliocene-Quaternary composite sediment samples from Sites 859,860 , and 862 . The younger group indicates that relatively rapid cooling of the source area occurred around $7 \pm 2 \mathrm{Ma}$, which seemingly postdates the time of initial collision at $15 \mathrm{Ma}$ in the Tierra del Fuego region $\sim 130 \mathrm{~km}$ to the south $\left(\sim 55^{\circ} \mathrm{S}\right)$. Detailed geophysical studies of the southern Chile margin have enabled reconstruction of plate geometries through the Cenozoic, which together with calculated convergence rates have been used to determine the timing of collision (e.g., Herron et al., 1981; Cande et al., 1987). These reconstructions also show that the first ridge segment which was about $700 \mathrm{~km}$ long, was not fully subducted until $\sim 10 \mathrm{Ma}$ at latitude $48^{\circ} \mathrm{S}$ (Forsythe and Nelson, 1985), and that three shorter ridge segments, separated by transform fault zones, have subsequently collided at 5-6 Ma, 2.5-4 $\mathrm{Ma}$, and 0.1 Ma (Herron et al., 1981; Forsythe and Nelson, 1985; Forsythe et al., 1986; Cande et al., 1987).

The $\sim 7$ Ma event indicated by the AFTA data records moderately rapid cooling of the source area in the late Miocene, possibly in response to collision of the first and/or second segment of the Chile ridge in the Golfo de Penas area. Unconformities of inferred PlioceneMiocene age are recognized in the sedimentary record, and have been attributed to uplift and erosion during ridge collision, together with other manifestations of collision such as Miocene plutons and volcanic centers and widespread faulting (Forsythe and Nelson, 1985). Similar effects of uplift and magmatism in the forearc region during the Pliocene have been documented in previous studies of the margin, and are interpreted to have occurred in response to collision of a third ridge segment in the Taitao area at $\sim 3 \mathrm{Ma}$ (Cande and Leslie, 1986; Forsythe et al., 1986). The distance between the drill sites, and the distance between the collision zone at $\sim 10-7 \mathrm{Ma}$ and these drill sites implies regional uplift of the Chile margin. Dickinson and Snyder 
(1979) proposed that uplift in this zone was the result of asthenospheric upwelling in the slab-free zone beneath the forearc and arc at the site of collision.

The older age population around $25 \mathrm{Ma}$ (late Oligocene) predates collision in the Golfo de Penas region; however, the distinct grouping of the data in the samples suggests that the $25 \pm 5 \mathrm{Ma}$ age records another discrete cooling event. A period of uplift and erosion at this time is consistent with recorded unconformities and overlying conglomerates in shelf basins to the north of the present-day triple junction (Cande and Leslie, 1986) and on the Taitao Peninsula to the south (Forsythe and Nelson, 1985). Although timing is not well constrained, the age controls suggest that erosion related to these unconformities occurred in the Oligocene to Miocene (Cande and Leslie, 1986; Forsythe and Nelson, 1985). Therefore, the AFTA data can be interpreted in terms of denudation of the source area.

Plate reconstructions show that at 25 million years ago, highly oblique convergence was occurring along the southern Chile margin, and had been since $\sim 40 \mathrm{Ma}$, with associated development of strike-slip faulting (Cande and Leslie, 1986). The north-south striking LiquineOfqui fault zone is a major crustal fault zone which lies adjacent to the Andean volcanic chain (Forsythe and Nelson 1985), and has a mapped strike length of approximately $1000 \mathrm{~km}$ until it trends offshore at the Golfo de Penas (Fig. 1). Both normal and dextral strike-slip movements have been documented; however, timing relationships are poorly constrained. Radiometric ages from the fault zone indicate a maximum age of $30 \mathrm{Ma}$ (Forsythe and Nelson, 1985), and it may be that the 25 Ma event reflects moderately rapid cooling due to deformation along the Liquine-Ofqui fault zone, or a similar fault zone, as a function of oblique subduction at that time.

\section{CONCLUSIONS}

The fission track data from detrital apatites in core recovered from Sites 859,860 , and 862 provide some useful results with which to interpret the tectonic evolution of the forearc and arc region of the southern Chile subduction zone. The main conclusions from analysis of individual fission track ages, track-length distributions and mean track lengths include the following:

1. There is no evidence for significant postdepositional heating of the sediments, that is, the sediments have remained at temperatures less than $60^{\circ} \mathrm{C}$ since deposition.

2. Two distinct age populations occur in all the samples analyzed: a younger age group centered on $\sim 7 \pm 2 \mathrm{Ma}$; and an older group at $\sim 25 \pm 5 \mathrm{Ma}$. Moderately rapid cooling, due to uplift and erosion of the source terrains through $\sim 110^{\circ} \mathrm{C}$ is the most likely interpretation of the AFTA data given the mixed sources represented in the sediments. However, cooling due to a rapid decline in heat flow cannot be ruled out with the present data.

3. The late Miocene event revealed by the AFTA data provides evidence for moderately rapid uplift and erosion of the source area and coincides with one or more collisions of ridge segments since initial collision of the Chile spreading ridge and the Chile trench 15 m.y. ago. Late Miocene uplift and magmatism associated with early episodes of ridge collision is analogous to the Pliocene magmatism and uplift documented by field and geophysical studies in this region when the third ridge segment collided.

4. The older age group found in the AFTA data may also indicate a cooling event, but clearly predates collision, and is probably related to deformation and denudation of the arc region as a consequence of highly oblique subduction. More specifically, it may relate to tectonism initiated along the Liquine-Ofqui fault zone at about $25-30 \mathrm{Ma}$.

This preliminary study highlights the usefulness of apatite fission track analysis for investigating the uplift history of source terrains in which the sediments derived from these sources lack a postdepositional thermal overprint. Further AFTA work on the onshore rocks of
Hole 859B

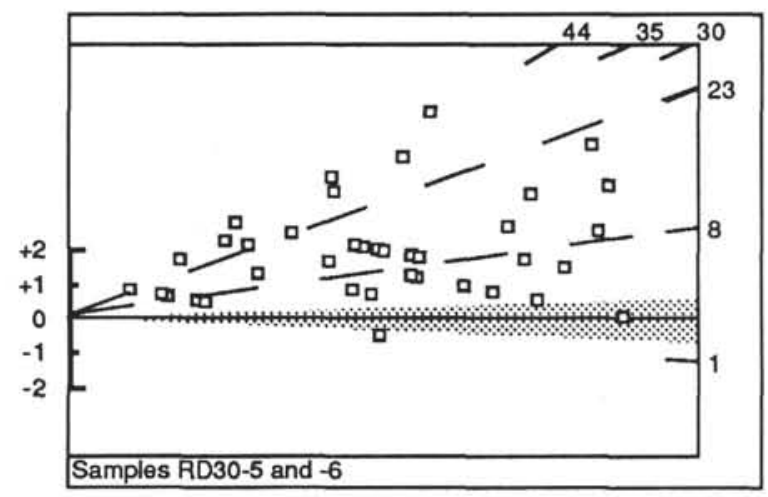

Hole 860B

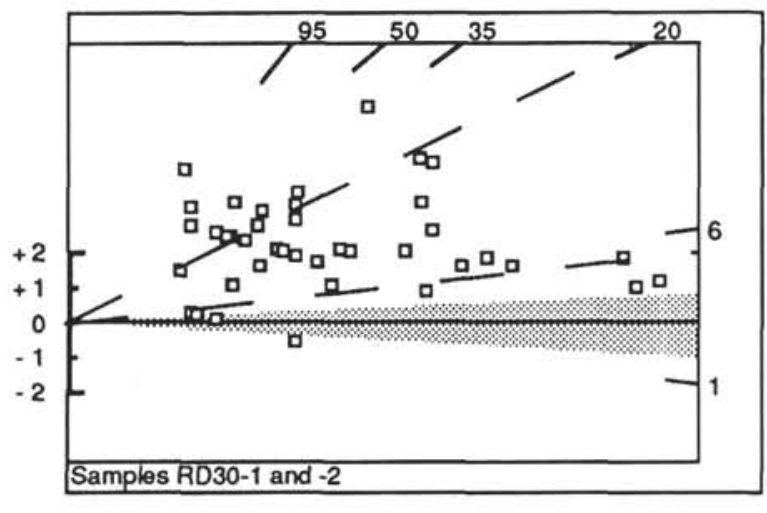

Hole 862A

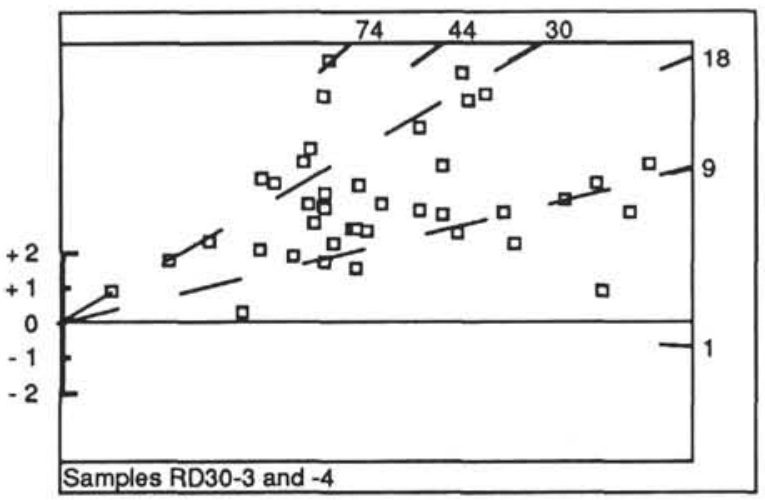

Figure 4. Radial plots (after Galbraith, 1988) for each of the three composite samples from Leg 141 holes. Ages in millions of years are shown around the top and right side of the plot, with open squares representing the fission track age of individual apatite grains. Stippled zone shows the range in stratigraphic age of the sample. Dashed lines indicate the younger and older age populations identified in each sample. The younger population for all samples is compatible with an age of $\sim 7 \mathrm{Ma}$, whereas the older population can be represented by an age of $\sim 25 \mathrm{Ma}$. See text for discussion and explanation of the radial plots. Uncertainties on each data point are $\pm 2 \sigma$. 
the southern Chile margin, both north and south of the present triple junction, would be extremely useful to compare with the data presented here for provenance studies and to further constrain the timing of events in this very active tectonic region.

\section{ACKNOWLEDGMENTS}

This study was made possible through financial support from the Australian ODP Secretariat and Geotrack International and the sampling efforts of the Leg 141 Shipboard Crew. Apatite separations and slide preparation undertaken by Peter Watson, Melanie Andersson, and Pat Kelly of Geotrack International is gratefully acknowledged. Thanks also to Paul O'Sullivan (La Trobe University) for fission track counting, Peter Watson for thin-section preparation and Sally Jacka for help with drafting the figures. We would also like to thank Ian Duddy for helpful discussions, and to Paul Green, David Foster, Paul Fitzgerald and Jan Behrmann for their critical reviews which greatly improved the manuscript. AFTA is a registered trademark of Geotrack International.

\section{REFERENCES}

Agar, S.M., Cliff, R.A., Duddy, I.R., and Rex, D.C., 1989. Accretion and uplift in the Shimanto Belt, SW Japan. J. Geol. Soc. London, 146:893-896.

Arne, D.C., 1992. Evidence from apatite fission-track analysis for regional Cretaceous cooling in the Ouachita Mountain Fold Belt and Arkoma Basin of Arkansas. AAPG Bull., 76:392-402.

Cande, S.C., and Leslie, R.B., 1986. Late Cenozoic tectonics of the southern Chile Trench. J. Geophys. Res., 91:471-496.

Cande, S.C., Leslie, R.B., Parra, J.C., and Hobart, M., 1987. Interaction between the Chile Ridge and Chile Trench: geophysical and geothermal evidence. J. Geophys, Res., 92:495-520.

Corrigan, J.D., and Crowley, K.D., 1990. Fission-track analysis of detrital apatites from Sites 717 and 718. Leg 116. Central Indian Ocean. In Cochran, J.R., Stow, D.A.V., et al., Proc. ODP, Sci. Results, 116: College Station, TX (Ocean Drilling Program), 75-92.

DeLong, S.E., and Fox, P.J., 1977. Geological consequences of ridge subduction. In Talwani, M., and Pitman, W.C., II (Eds.), Island Arcs, Deep Sea Trenches, and Back-arc Basins. Am. Geophys. Union, Maurice Ewing Ser., 1:221-228.

DeLong, S.E., Fox, P.J., and McDowell, F.W., 1979. Subduction of the Kula Ridge at the Aleutian Trench. Geol. Soc. Am. Bull., 89:83-95.

Dickinson, W.R., and Snyder, W.S., 1979. Geometry of subducted slabs related to San Andreas Transform. J. Geol., 87:609-627.

Duddy, I.R., Gleadow, A.J.W., and Keene, J.B., 1984. Fission track dating of apatite and sphene from Paleogene sediments of Deep Sea Drilling Project Leg 81, Site 555. In Roberts, D.G., Schnitker, D., et al., Init. Repts. DSDP. 81: Washington (U.S. Govt. Printing Office), 725-729.

Duddy, I.R., Green, P.F., and Laslett, G.M., 1988. Thermal annealing of fission tracks in apatite-3. Variable temperature behavior. Chem. Geol., 73:25-38.

Forsythe, R.D., and Nelson, E., 1985. Geological manifestations of ridge collision: evidence from the Golfo de Penas-Taitao Basin, southern Chile. Tectonics, 4:477-495.

Forsythe, R.D., Nelson, E.P., Carr, M.J., Kaeding, M.E., Herve, M., Mpodozis, C., Soffia, J.M., and Harambour, S., 1986. Pliocene near-trench magmatism in southern Chile: a possible manifestation of ridge collision. Geology, 14:23-27.
Galbraith, R.F., 1988. Graphical display of estimates having differing standard errors. Technometrics, 30:271-281.

Gleadow, A.J.W., 1981. Fission track dating methods: what are the real alternatives? Nucl. Tracks, 5:3-14.

Gleadow, A.J.W., Duddy, I.R., Green, P.F., and Lovering, J.F., 1986. Confined track lengths in apatite - a diagnostic tool for thermal history analysis. Contrib. Mineral. Petrol., 94:405-415.

Gleadow, A.J.W., Duddy, I.R., and Lovering, J.F., 1983. Fission track analysis: a new tool for the evaluation of thermal histories and hydrocarbon potential. APEA J., 23:93-102.

Green, P.F., 1988. The relationship between track shortening and fission track age reduction in apatite: combined influences of inherent instability, annealing anisotropy, length bias and system calibration. Earth Planet. Sci. Lett., 89:335-352.

Green, P.F., Duddy, I.R., Gleadow, A.J.W., Tingate, P.R., and Laslett, G.M., 1985. Fission-track annealing in apatite: track length measurements and the form of the Arrhenius plot. Nucl. Tracks, 10:323-328. 1986. Thermal annealing of fission tracks in apatite 1. A quantitative description. Chem. Geol., 59:237-253.

Green, P.F., Duddy, I.R., Laslett, G.M., Hegarty, K.A., Gleadow, A.J.W., and Lovering, J.R., 1989. Thermal annealing of fission tracks in apatite 4. Quantitative modelling techniques and extension to geological time-scales. Chem. Geol., 79:155-182.

Harland, W.B., Armstrong, R.L., Cox, A.V., Craig, L.E., Smith, A.G., and Smith, D.G., 1990. A Geologic Time Scale 1989: Cambridge (Cambridge Univ. Press).

Herron, E.M., Cande, S.C., and Hall, B.R., 1981. An active spreading center collides with a subduction zone: a geophysical survey of the Chile margin triple junction. Mem.-Geol. Soc. Am., 154:683-701.

Hurford, A.J., and Carter, A., 1991. The role of fission track dating in discrimination of provenance. In Morton, A.C., Todd, S.P., and Haughton, P.D.W. (Eds.), Developments in Sedimentary Provenance Studies. Geol. Soc. Spec. Publ. London, 57:67-78.

Hurford, A.J., and Green, P.F., 1982. A user's guide to fission-track dating calibration. Earth Planet. Sci. Lett., 59:343-354.

Kamp, P.J.J., Green, P.F., and White, S.H., 1989. Fission track analysis reveals character of collisional tectonics in New Zealand. Tectonics, 3:169-195.

Laslett, G.M., Green, P.F., Duddy, I.R., and Gleadow, A.J.W., 1987. Thermal annealing of fission tracks in apatite-2. A quantitative analysis. Chem. Geol., 65:1-15.

Laslett, G.M., Kendall, W.S., Gleadow, A.J.W., and Duddy, I.R., 1982. Bias in measurement of fission-track length distributions. Nucl. Tracks, 6:79-85.

Marshak, R.S., and Karig, D.E., 1977. Triple junctions as a cause for anomalously near-trench igneous activity between the trench and the volcanic arc. Geology, 5:233-236.

Naeser, C.W., 1981. The fading of fission tracks in the geologic environmentdata from deep boreholes. Nucl. Tracks, 5:248-250. (Abstract)

\footnotetext{
Abbreviations for names of organizations and publications in ODP reference lists follow the style given in Chemical Abstracts Service Source Index (published by American Chemical Society).
}

Date of initial receipt: 23 April 1993

Date of acceptance: 29 November 1993

Ms 141SR-038 


\section{APPENDIX}

\section{Fission Track Age Data}

\section{Definitions of terms used as column headings}

$\mathrm{Ns}=$ number of spontaneous tracks counted; $\mathrm{Ni}=$ number of induced tracks counted: $\mathrm{Na}=$ number of microscope grid units in which tracks were counted, where the area of basic unit $=6.293 \times 10^{-7} \mathrm{~cm}^{2} ;$ Ratio $=$ ratio of spontaneous tracks to induced tracks counted $(\mathrm{Ns} / \mathrm{Ni}) ; \mathrm{RHOs}=$ density of spontaneous tracks $\left(\right.$ tracks $\left./ \mathrm{cm}^{2}\right) ; \mathrm{RHOi}=$ density of induced tracks $\left(\right.$ tracks $\left./ \mathrm{cm}^{2}\right) ; \mathrm{Age}=$ single grain fission track age $\pm 1 \sigma$ error in millions of years.

\section{Definitions of terms given below the tables}

Chi squared $=\chi^{2}$, used to assess variation of single grain ages within the sample. $\mathrm{P}$ (chi squared $)=$ probability of obtaining observed $\chi^{2}$ value for the relevant number of degrees of freedom. If all the grains belong to a single population then $\mathrm{P}\left(\chi^{2}\right)>5 \%$. Correlation Coefficient $=$ correlation coefficient between $\mathrm{Ns}$ and $\mathrm{Ni}$. Age dispersion $=\%$ variation in single grain ages

\section{Values used in age calculation}

Zeta calibration factor $=$ calibration constant determined empirically for the observer. RhoD = density of tracks from uranium standard glass. $\mathrm{ND}=$ total number of tracks counted for determining track density. Pooled age $=$ fission track age calculated from pooled ratio $\mathrm{Ns} / \mathrm{Ni}$, which is valid only when $\mathrm{P}\left(\chi^{2}\right)$ $>5 \%$. Central age $=$ alternative to pooled age when $\mathrm{P}\left(\chi^{2}\right)<5 \%$.

Appendix Table 1. Analytical data for sample RD30-1 (Hole 860B).

\begin{tabular}{|c|c|c|c|c|c|c|c|c|}
\hline Grain & Ns & $\mathrm{Ni}$ & $\mathrm{Na}$ & Ratio & $\underset{(\mathrm{ppm})}{\mathrm{U}}$ & RHOs & RHOi & $\begin{array}{l}\text { Age } \\
\text { (Ma) }\end{array}$ \\
\hline I & 5 & 40 & 16 & 0.125 & 35.6 & $4.966 E+05$ & $3.973 \mathrm{E}+06$ & $32.1 \pm 15.2$ \\
\hline 2 & 7 & 204 & 30 & 0.034 & 97.0 & $3.708 \mathrm{E}+05$ & $1,081 \mathrm{E}+07$ & $8.8 \pm 3.4$ \\
\hline 3 & 5 & 176 & 28 & 0.028 & 89.6 & $2.838 \mathrm{E}+05$ & $9.988 \mathrm{E}+06$ & $7.3 \pm 3.3$ \\
\hline 4 & 3 & 66 & 42 & 0.045 & 22.4 & $1.135 E+05$ & $2.497 \mathrm{E}+06$ & $11.7 \pm 6.9$ \\
\hline 5 & 3 & 21 & 21 & 0.143 & 14.3 & $2.270 \mathrm{E}+05$ & $1.589 \mathrm{E}+06$ & $36.7 \pm 22.7$ \\
\hline 6 & 4 & 20 & 20 & 0.200 & 14.3 & $3.178 \mathrm{E}+05$ & $1.589 E+06$ & $51.3 \pm 28.1$ \\
\hline 7 & 4 & 53 & 25 & 0.075 & 30.2 & $2.542 \mathrm{E}+0.5$ & $3.369 E+06$ & $19.4 \pm 10.1$ \\
\hline 8 & 6 & 271 & 40 & 0.022 & 96.6 & $2.384 \mathrm{E}+05$ & $1.077 \mathrm{E}+07$ & $5.7 \pm 2.4$ \\
\hline 9 & 0 & 35 & 20 & 0.000 & 25.0 & $0.000 \mathrm{E}+00$ & $2.781 E+06$ & $0.0 \pm 0.0$ \\
\hline 10 & 13 & 183 & 20 & 0.071 & 130.5 & $1.033 \mathrm{E}+06$ & $1.454 \mathrm{E}+07$ & $18.3 \pm 5.3$ \\
\hline 11 & 5 & 78 & 20 & 0.064 & 55.6 & $3.973 \mathrm{E}+05$ & $6.197 E+06$ & $16.5 \pm 7.6$ \\
\hline 12 & 0 & 82 & 32 & 0.000 & 36.5 & $0.000 \mathrm{E}+00$ & $4.072 E+06$ & $0.0 \pm 0.0$ \\
\hline 13 & 2 & 57 & 28 & 0.035 & 29.0 & $1.135 \mathrm{E}+06$ & $3.235 E+06$ & $9.0 \pm 6.5$ \\
\hline 14 & 0 & 24 & 28 & 0.000 & 12.2 & $0.000 \mathrm{E}+00$ & $1.362 E+06$ & $0.0 \pm 0.0$ \\
\hline 15 & 6 & 76 & 24 & 0.079 & 45.2 & $3.973 E+05$ & $5.032 \mathrm{E}+06$ & $20.3 \pm 8.6$ \\
\hline 16 & 3 & 39 & 50 & 0.077 & 11.1 & $9.534 \mathrm{E}+04$ & $1.239 \mathrm{E}+06$ & $19.8 \pm 11.9$ \\
\hline 17 & 6 & 16 & 21 & 0.375 & 10.9 & $4.540 \mathrm{E}+0.5$ & 1.211E + 06 & $95.8 \pm 45.9$ \\
\hline 18 & 7 & 77 & 20 & 0.091 & 54.9 & $5.562 E+05$ & $6.118 \mathrm{E}+06$ & $23.4 \pm 9.2$ \\
\hline 19 & 17 & 125 & 50 & 0.136 & 35.6 & $5.403 E+05$ & $3.973 E+06$ & $34.9 \pm 9.1$ \\
\hline \multirow[t]{2}{*}{20} & 13 & 197 & 28 & 0.066 & 100.3 & $7.378 \mathrm{E}+05$ & $1.118 \mathrm{E}+07$ & $17.0 \pm 4.9$ \\
\hline & 109 & 1840 & & & 46.6 & $3.077 \mathrm{E}+05$ & $5.193 \mathrm{E}+06$ & $15.2 \pm 1.6$ \\
\hline
\end{tabular}


Appendix Table 2. Analytical data for sample RD30-2 (Hole 860B).

\begin{tabular}{|c|c|c|c|c|c|c|c|c|}
\hline Grain & Ns & $\mathrm{Ni}$ & $\mathrm{Na}$ & Ratio & $\underset{(\mathrm{ppm})}{\mathrm{U}}$ & RHOS & RHOi & $\begin{array}{l}\text { Age } \\
\text { (Ma) }\end{array}$ \\
\hline 1 & 3 & 96 & 49 & 0.031 & 30.2 & $9.729 E+04$ & $3.113 E+06$ & $7.4 \pm 4.4$ \\
\hline 2 & 5 & 240 & 60 & 0.021 & 61.7 & $1.324 E+05$ & $6.356 \mathrm{E}+06$ & $5.0 \pm 2.2$ \\
\hline 3 & 6 & 307 & 48 & 0.020 & 98.6 & $1.986 \mathrm{E}+05$ & $1.016 \mathrm{E}+07$ & $4.7 \pm 1.9$ \\
\hline 4 & 3 & 32 & 40 & 0.094 & 12.3 & $1.192 \mathrm{E}+05$ & $1.271 E+06$ & $22.3 \pm 1.3 .5$ \\
\hline 5 & 3 & 37 & 24 & 0.081 & 23.8 & $1.986 E+05$ & $2.450 \mathrm{E}+06$ & $19.3 \pm 11.6$ \\
\hline 6 & 4 & 114 & 70 & 0.035 & 25.1 & $9.080 \mathrm{E}+04$ & $2.588 \mathrm{E}+06$ & $8.3 \pm 4.3$ \\
\hline 7 & 3 & 79 & 24 & 0.038 & 50.8 & $1.986 E+05$ & $5.231 \mathrm{E}+06$ & $9.0 \pm 5.3$ \\
\hline 8 & 9 & 189 & 60 & 0.048 & 48.6 & $2.384 E+05$ & $5.006 E+06$ & $11.3 \pm 3.9$ \\
\hline 9 & 2 & 108 & 80 & 0.019 & 20.8 & $3.973 \mathrm{E}+04$ & $2.145 \mathrm{E}+06$ & $4.4 \pm 3.1$ \\
\hline 10 & 4 & 122 & 60 & 0.033 & 31.4 & $1.059 E+05$ & $3.231 \mathrm{E}+06$ & $7.8 \pm 4.0$ \\
\hline 11 & 5 & 55 & 35 & 0.091 & 24.2 & $2.270 \mathrm{E}+05$ & $2.497 E+06$ & $21.6 \pm 10.1$ \\
\hline 12 & 0 & 27 & 48 & 0.000 & 8.7 & $0.000 \mathrm{E}+00$ & $8.938 \mathrm{E}+05$ & $0.0 \pm 0.0$ \\
\hline 13 & 7 & 503 & 100 & 0.014 & 77.6 & 1.112E+05 & $7.993 E+06$ & $3.3 \pm 1.3$ \\
\hline 14 & 3 & 201 & 60 & 0.015 & 51.7 & $7.945 \mathrm{E}+04$ & $5.323 E+06$ & $3.6 \pm 2.1$ \\
\hline 15 & 3 & 47 & 18 & 0.064 & 40.3 & $2.648 \mathrm{E}+05$ & $4.149 E+06$ & $15.2 \pm 9.0$ \\
\hline 16 & 8 & 543 & 100 & 0.015 & 83.7 & $1.271 E+05$ & $8.629 E+06$ & $3.5 \pm 1.3$ \\
\hline 17 & 1 & 19 & 80 & 0.053 & 3.7 & $1.986 E+04$ & $3.774 \mathrm{E}+05$ & $12.5 \pm 12.8$ \\
\hline 18 & 9 & 477 & 100 & 0.019 & 73.5 & $1.430 \mathrm{E}+05$ & $7.580 \mathrm{E}+06$ & $4.5 \pm 1.5$ \\
\hline 19 & 3 & 71 & 18 & 0.042 & 60.8 & $2.648 E+05$ & $6.268 E+06$ & $10.1 \pm 5.9$ \\
\hline \multirow[t]{2}{*}{20} & 1 & 42 & 48 & 0.024 & 13.5 & $3.311 \mathrm{E}+04$ & $1.390 E+06$ & $5.7 \pm 5.7$ \\
\hline & 82 & 3309 & & & 45.5 & $1.161 \mathrm{E}+05$ & $4.686 \mathrm{E}+06$ & $-5.9 \pm 0.7$ \\
\hline
\end{tabular}

Notes: Chi squared $=35.579$ for 19 degrees of freedom: $P($ chi squared $)=1.2 \%$. Correlation coefficient $=$ 0.801 ; age dispersion $=31.277 \%$. Zeta calibration factor of $352.7 \pm 5$ for SRM612 reference glass, $R h o D=1.350 \mathrm{E}+06 \mathrm{~cm}^{-2}: \mathrm{ND}=2120$. Pooled age $=5.9 \pm 0.7 \mathrm{Ma}$. Central age $=6.7 \pm 0.9 \mathrm{Ma}$.

Appendix Table 3. Analytical data for sample RD30-3 (Hole 862A).

\begin{tabular}{|c|c|c|c|c|c|c|c|c|}
\hline Grain & $\mathrm{Ns}$ & $\mathrm{Ni}$ & $\mathrm{Na}$ & Ratio & $\underset{(\mathrm{ppm})}{\mathrm{U}}$ & RHOS & RHOi & $\begin{array}{l}\text { Age } \\
\text { (Mi) }\end{array}$ \\
\hline 1 & 2 & 23 & 60 & 0.087 & 5.5 & $5.297 \mathrm{E}+04$ & $6.091 \mathrm{E}+05$ & $22.3 \pm 16.5$ \\
\hline 2 & 18 & 62 & 36 & 0.290 & 24.6 & $7.945 E+05$ & $2.737 \mathrm{E}+06$ & $74.3 \pm 20.0$ \\
\hline 3 & 9 & 351 & 80 & 0.026 & 62.6 & $1.788 \mathrm{E}+05$ & $6.972 E+06$ & $6.6 \pm 2.2$ \\
\hline 4 & 5 & 224 & 48 & 0.022 & 66.5 & $1.655 E+05$ & $7.416 \mathrm{E}+06$ & $5.7 \pm 2.6$ \\
\hline 5 & 17 & 167 & 56 & 0.102 & 42.5 & $4.824 \mathrm{E}+05$ & $4.739 \mathrm{E}+06$ & $26.2 \pm 6.7$ \\
\hline 6 & 1 & 12 & 50 & 0.083 & 3.4 & $3.178 \mathrm{E}+04$ & $3.814 \mathrm{E}+05$ & $21.4 \pm 22.3$ \\
\hline 7 & 2 & 76 & 60 & 0.026 & 18.1 & $5.297 E+04$ & $2.013 E+06$ & $6.8 \pm 4.9$ \\
\hline 8 & 4 & 100 & 90 & 0.040 & 15.8 & $7.063 \mathrm{E}+04$ & $1.766 \mathrm{E}+06$ & $10.3 \pm 5.3$ \\
\hline 9 & 6 & 39 & 25 & 0.154 & 22.2 & $3.814 \mathrm{E}+05$ & $2.479 E+06$ & $39.5 \pm 17.3$ \\
\hline 10 & 5 & 71 & 100 & 0.070 & 10.1 & $7.945 E+04$ & $1.128 E+06$ & $18.1 \pm 8.4$ \\
\hline 11 & 5 & 63 & 60 & 0.079 & 15.0 & $1.324 \mathrm{E}+0.5$ & $1.669 E+06$ & $20.4 \pm 9.5$ \\
\hline 12 & 9 & 60 & 56 & 0.150 & 15.3 & $2.554 \mathrm{E}+0.5$ & $1.703 E+06$ & $38.5 \pm 13.8$ \\
\hline 13 & 14 & 371 & 100 & 0.038 & 52.9 & $2.225 E+05$ & $5.895 E+06$ & $9.7 \pm 2.7$ \\
\hline 14 & 3 & 80 & 35 & 0.038 & 32.6 & $1.362 \mathrm{E}+05$ & $3.632 E+06$ & $9.6 \pm 5.7$ \\
\hline 15 & 10 & 153 & 70 & 0.065 & 31.2 & $2.270 \mathrm{E}+05$ & $3.473 E+06$ & $16.8 \pm 5.5$ \\
\hline 16 & 11 & 307 & 30 & 0.036 & 145.9 & $5.827 \mathrm{E}+05$ & $1.626 \mathrm{E}+07$ & $9.2 \pm 2.8$ \\
\hline 17 & 18 & 181 & 35 & 0.099 & 73.7 & $8.172 \mathrm{E}+05$ & $8.218 E+06$ & $25.6 \pm 6.3$ \\
\hline 18 & 6 & 157 & 36 & 0.038 & 62.2 & $2.648 E+05$ & $6.930 E+06$ & $9.8 \pm 4.1$ \\
\hline 19 & 6 & 1.37 & 60 & 0.044 & 32.6 & $1.589 E+0.5$ & $3.628 \mathrm{E}+06$ & $11.3 \pm 4.7$ \\
\hline \multirow[t]{2}{*}{20} & 4 & 91 & 56 & 0.044 & 23.2 & $1.135 E+05$ & $2.582 E+06$ & $11.3 \pm 5.8$ \\
\hline & 155 & 2725 & & & 34.0 & $2.155 \mathrm{E}+05$ & $3.788 \mathrm{E}+06$ & $14.6 \pm 1.3$ \\
\hline
\end{tabular}

Notes: Chi squared $=90.452$ for 19 degrees of freedom: $\mathrm{P}$ (chi squared) $=<0.1 \%$. Correlation coefficient $=0.456$ : age dispersion $=66.175 \%$. Zeta calibration factor of $352.7 \pm 5$ for SRM6I2 reference glass. RhoD $=1.460 \mathrm{E}$ $+06 \mathrm{~cm}^{-2}: \mathrm{ND}=2233$. Pooled age $=14.6 \pm 1.3 \mathrm{Ma}$. Central age $=17.8 \pm 3.1 \mathrm{Ma}$. 
Appendix Table 4. Analytical data for sample RD30-4 (Hole 862A).

\begin{tabular}{|c|c|c|c|c|c|c|c|c|}
\hline Grain & Ns & $\mathrm{Ni}$ & $\mathrm{Na}$ & Ratio & $\underset{(\mathrm{ppm})}{U}$ & RHOs & RHOi & $\begin{array}{l}\text { Age } \\
\text { (Ma) }\end{array}$ \\
\hline 1 & 14 & 62 & 60 & 0.226 & 14.7 & $3.708 E+05$ & $1.624 E+06$ & $57.9 \pm 17.2$ \\
\hline 2 & 6 & 45 & 49 & 0.133 & 13.1 & $1.946 E+05$ & $1.459 E+06$ & $34.2 \pm 14.9$ \\
\hline 3 & 7 & 92 & 25 & 0.076 & 52.5 & $4.449 E+05$ & $5.848 \mathrm{E}+06$ & $19.6 \pm 7.7$ \\
\hline 4 & 7 & 211 & 30 & 0.033 & 100.3 & $3.708 \mathrm{E}+05$ & $1.118 E+07$ & $8.5 \pm 3.3$ \\
\hline 5 & 2 & 58 & 16 & 0.034 & 51.7 & $1.986 E+05$ & $5.760 \mathrm{E}+06$ & $8.9 \pm 6.4$ \\
\hline 6 & 0 & 3 & 35 & 0.000 & 1.2 & $0.000 E+00$ & $1.362 \mathrm{E}+05$ & $0.0 \pm 0.0$ \\
\hline 7 & 5 & 170 & 25 & 0.029 & 97.0 & $3.178 \mathrm{E}+05$ & $1.081 E+07$ & $7.6 \pm 3.4$ \\
\hline 8 & 4 & 94 & 21 & 0.043 & 6.8 & $3.027 \mathrm{E}+0.5$ & $7.113 E+06$ & $10.9 \pm 5.6$ \\
\hline 9 & 8 & 58 & 100 & 0.138 & 8.3 & $1.271 \mathrm{E}+0.5$ & $9.217 \mathrm{E}+05$ & $35.4 \pm 1.3 .4$ \\
\hline 10 & 20 & 158 & 28 & 0.127 & 80.5 & $1.135 E+06$ & $8.967 E+06$ & $32.5 \pm 7.8$ \\
\hline 11 & 3 & 324 & 60 & 0.009 & 77.0 & $7.945 E+04$ & $8.581 E+06$ & $2.4 \pm 1.4$ \\
\hline 12 & 2 & 96 & 48 & 0.021 & 28.5 & $6.621 \mathrm{E}+04$ & $3.178 \mathrm{E}+06$ & $5.4 \pm 3.8$ \\
\hline 13 & 4 & 68 & 50 & 0.0 .59 & 19.4 & $1.271 \mathrm{E}+0.5$ & $2.161 \mathrm{E}+06$ & $15.1 \pm 7.8$ \\
\hline 14 & 2 & 42 & 50 & 0.048 & 12.0 & $6.356 \mathrm{E}+04$ & $1.335 E+06$ & $12.2 \pm 8.9$ \\
\hline 15 & 6 & 72 & 16 & 0.083 & 64.2 & $5.959 \mathrm{E}+05$ & $7.151 E+06$ & $21.4 \pm 9.1$ \\
\hline 16 & 13 & 131 & 60 & 0.099 & 31.1 & $3.443 \mathrm{E}+0.5$ & $3.469 \mathrm{E}+06$ & $25.5 \pm 7.4$ \\
\hline 17 & 9 & 273 & 60 & 0.033 & 64.9 & $2.384 E+05$ & $7.230 \mathrm{E}+06$ & $8.5 \pm 2.9$ \\
\hline 18 & 5 & 73 & 35 & 0.068 & 29.7 & $2.270 \mathrm{E}+05$ & $3.314 E+06$ & $17.6 \pm 8.2$ \\
\hline 19 & 0 & 37 & 36 & 0.000 & 14.7 & $0.000 \mathrm{E}+00$ & $1.633 E+06$ & $0.0 \pm 0.0$ \\
\hline \multirow[t]{2}{*}{20} & 6 & 108 & 100 & 0.056 & 15.4 & $9.534 E+04$ & $1.716 \mathrm{E}+06$ & $14.3 \pm 6.0$ \\
\hline & 123 & 2175 & & & 34.3 & $2.162 E+05$ & $3.823 \mathrm{E}+06$ & $14.5 \pm 1.4$ \\
\hline
\end{tabular}

Notes: Chi squared $=77.987$ for 19 degrees of freedom: $P($ chi squared $)=<0.1 \%$. Correlation coefficient $=0.257$; age dispersion $=62.914 \%$. Zeta calibration factor of $352.7 \pm 5$ for $S R M 612$ reference glass. $R$ hoD $=1.460 E$ $+06 \mathrm{~cm}^{-2}: \mathrm{ND}=223.3$. Pooled age $=14.5 \pm 1.4 \mathrm{Ma}$. Central age $=6.7 \pm 2.9 \mathrm{Ma}$

Appendix Table 5. Analytical data for sample RD30-5 (Hole 859B).

\begin{tabular}{|c|c|c|c|c|c|c|c|c|}
\hline Grain & Ns & $\mathrm{Ni}$ & $\mathrm{Na}$ & Ratio & $\underset{(\mathrm{ppm})}{\mathrm{U}}$ & RHOs & RHOi & $\begin{array}{l}\text { Age } \\
\text { (Ma) }\end{array}$ \\
\hline 1 & 6 & 144 & 16 & 0.042 & 128.3 & $5.959 E+05$ & 1. $430 \mathrm{E}+07$ & $10.7 \pm 4.5$ \\
\hline 2 & 2 & 17 & 9 & 0.118 & 26.9 & $3.531 \mathrm{E}+05$ & $3.002 \mathrm{E}+06$ & $30.2 \pm 22.6$ \\
\hline 3 & 2 & 93 & 9 & 0.022 & 147.3 & $3.531 \mathrm{E}+05$ & $1.642 \mathrm{E}+07$ & $5.5 \pm 4.0$ \\
\hline 4 & 15 & 87 & 20 & 0.172 & 62.0 & $1.192 E+06$ & $6.912 \mathrm{E}+06$ & $44.2 \pm 12.4$ \\
\hline 5 & 2 & 237 & 49 & 0.008 & 69.0 & $6.486 E+04$ & $7.686 \mathrm{E}+06$ & $2.2 \pm 1.5$ \\
\hline 6 & 0 & 8 & 60 & 0.000 & 1.9 & $0.000 E+00$ & $2.119 E+05$ & $0.0 \pm 0.0$ \\
\hline 7 & 6 & 144 & 30 & 0.042 & 68.4 & $3.178 \mathrm{E}+05$ & $7.628 E+06$ & $10.7 \pm 4.5$ \\
\hline 8 & 3 & 65 & 12 & 0.046 & 77.2 & $3.973 \mathrm{E}+05$ & $8.607 E+06$ & $11.9 \pm 7.0$ \\
\hline 9 & 0 & 76 & 24 & 0.000 & 45.2 & $0.000 \mathrm{E}+00$ & $5.032 \mathrm{E}+06$ & $0.0 \pm 0.0$ \\
\hline 10 & 1 & 62 & 30 & 0.016 & 29.5 & $5.297 \mathrm{E}+04$ & $3.284 \mathrm{E}+06$ & $4.2 \pm 4.2$ \\
\hline II & 3 & 72 & 20 & 0.042 & 51.3 & $2.384 \mathrm{E}+05$ & $5.721 \mathrm{E}+06$ & $10.7 \pm 6.3$ \\
\hline 12 & 10 & 77 & 48 & 0.130 & 22.9 & $3.311 \mathrm{IE}+05$ & $2.549 \mathrm{E}+06$ & $33.4 \pm 11.2$ \\
\hline 13 & 15 & 197 & 49 & 0.076 & 57.3 & $4.864 \mathrm{E}+05$ & $6.389 E+06$ & $19.6 \pm 5.3$ \\
\hline 14 & 3 & 61 & 16 & 0.049 & 54.4 & $2980 \mathrm{E}+05$ & $6.058 \mathrm{E}+06$ & $12.6 \pm 7.5$ \\
\hline 15 & 1 & 71 & 28 & 0.014 & 36.2 & $5.675 E+04$ & $4.029 E+06$ & $3.6 \pm 3.7$ \\
\hline 16 & 0 & 13 & 24 & 0.000 & 7.7 & $0.000 E+00$ & $8.607 \mathrm{E}+0.5$ & $0.0 \pm 0.0$ \\
\hline 17 & 7 & 47 & 21 & 0.149 & 31.9 & $5.297 \mathrm{E}+05$ & $3.556 \mathrm{E}+06$ & $38.2 \pm 15.5$ \\
\hline 18 & 7 & 211 & 16 & 0.033 & 188.0 & $6.952 E+05$ & $2.096 \mathrm{E}+07$ & $8.5 \pm 3.3$ \\
\hline 19 & 6 & 49 & 9 & 0.122 & 77.6 & $1.059 \mathrm{E}+06$ & $8.652 \mathrm{E}+06$ & $31.4 \pm 13.6$ \\
\hline \multirow[t]{2}{*}{20} & i & 27 & 18 & 0.037 & 21.4 & $8.828 \mathrm{E}+04$ & $2.384 \mathrm{E}+06$ & $9.5 \pm 9.7$ \\
\hline & 90 & 1758 & & & 49.3 & $2.81 .5 \mathrm{E}+0.5$ & $5.499 \mathrm{E}+06$ & $13.2 \pm 1.5$ \\
\hline
\end{tabular}

Notes: Chi squared $=65.359$ for 19 degrees of freedom: $P$ (chi squared $)=\langle 0.1 \%$. Correlation coefficient $=$ 0.421: Age dispersion $=71.009 \%$. Zeta calibration factor of $352.7 \pm 5$ for SRM612 reference glass. $R h o D=1.460 E+06 \mathrm{~cm}^{-2}: \mathrm{ND}=22.33$. Pooled age $=13.2 \pm 1.5 \mathrm{Ma}$. Central age $=14.2 \pm 2.9 \mathrm{Ma}$. 
Appendix Table 6. Analytical data for sample RD30-6 (Hole 859B).

\begin{tabular}{|c|c|c|c|c|c|c|c|c|}
\hline Grain & Ns & $\mathrm{Ni}$ & $\mathrm{Na}$ & Ratio & $\begin{array}{c}\mathrm{U} \\
(\mathrm{ppm})\end{array}$ & RHOs & RHOi & $\begin{array}{l}\text { Age } \\
\text { (Ma) }\end{array}$ \\
\hline 1 & 2 & 168 & 70 & 0.012 & 34.2 & $4.540 E+04$ & $3.814 \mathrm{E}+06$ & $3.1 \pm 2.2$ \\
\hline 2 & 2 & 23 & 24 & 0.087 & 13.7 & $1.324 E+05$ & $1.523 E+06$ & $22.3 \pm 16.5$ \\
\hline 3 & 11 & 215 & 50 & 0.051 & 61.3 & $3.496 \mathrm{E}+0.5$ & $6.833 E+06$ & $13.2 \pm 4.1$ \\
\hline 4 & 3 & 19 & 50 & 0.158 & 5.4 & $9.534 E+04$ & $6.038 \mathrm{E}+05$ & $40.5 \pm 25.2$ \\
\hline 5 & 0 & 3 & 16 & 0.000 & 2.7 & $0.000 E+00$ & $2.980 \mathrm{E}+0.5$ & $0.0 \pm 0.0$ \\
\hline 6 & 9 & 157 & 36 & 0.057 & 62.2 & $3.973 E+05$ & $6.930 \mathrm{E}+06$ & $14.7 \pm 5.1$ \\
\hline 7 & 2 & 120 & 30 & 0.017 & 57.0 & $1.059 E+05$ & $6.356 \mathrm{E}+06$ & $4.3 \pm 3.1$ \\
\hline 8 & 2 & 51 & 12 & 0.039 & 60.6 & $2.648 E+0.5$ & $6.754 \mathrm{E}+06$ & $10.1 \pm 7.3$ \\
\hline 9 & 3 & 75 & 50 & 0.040 & 21.4 & $9.534 E+04$ & $2.384 E+06$ & $10.3 \pm 6.1$ \\
\hline 10 & 3 & 75 & 30 & 0.040 & 35.6 & $1.589 E+0.5$ & $3.973 E+06$ & $10.3 \pm 6.1$ \\
\hline 11 & 2 & 138 & 60 & 0.014 & 32.8 & $5.297 E+04$ & $3.655 E+06$ & $3.7 \pm 2.7$ \\
\hline 12 & 2 & 90 & 49 & 0.022 & 26.2 & $6.486 \mathrm{E}+04$ & $2.919 \mathrm{E}+06$ & $5.7 \pm 4.1$ \\
\hline 13 & $i$ & 9 & 56 & 0.111 & 2.3 & $2.838 E+04$ & $2.554 \mathrm{E}+0.5$ & $28.5 \pm 30.1$ \\
\hline 14 & 3 & 88 & 28 & 0.034 & 44.8 & $1.703 \mathrm{E}+05$ & $4.994 \mathrm{E}+06$ & $8.8 \pm 5.2$ \\
\hline 15 & 0 & 7 & 28 & 0.000 & 3.6 & $0.000 E+00$ & $3.973 E+05$ & $0.0 \pm 0.0$ \\
\hline 16 & 0 & 15 & 36 & 0.000 & 5.9 & $0.000 E+00$ & $6.621 \mathrm{E}+05$ & $0.0 \pm 0.0$ \\
\hline 17 & 3 & 93 & 56 & 0.032 & 23.7 & $8.513 E+04$ & $2.639 E+06$ & $8.3 \pm 4.9$ \\
\hline 18 & 4 & 157 & 42 & 0.025 & 53.3 & $1.513 E+05$ & $5.940 \mathrm{E}+06$ & $6.6 \pm 3.3$ \\
\hline 19 & 3 & 36 & 20 & 0.083 & 25.7 & $2.384 \mathrm{E}+05$ & $2.860 \mathrm{E}+06$ & $21.4 \pm 12.9$ \\
\hline \multirow[t]{2}{*}{20} & 4 & 187 & 60 & 0.021 & 44.4 & $1.059 E+05$ & $4.953 \mathrm{E}+06$ & $5.5 \pm 2.8$ \\
\hline & 59 & 1726 & & & 30.6 & $1.168 E+05$ & $3.416 \mathrm{E}+06$ & $8.8 \pm 1.2$ \\
\hline
\end{tabular}

Notes: Chi squared $=24.514$ for 19 degrees of freedom: $P$ (chi squared) $=17.7 \%$. Correlation coefficient $=0.705$; age dispersion $=19.695 \%$. Zeta calibration factor of $352.7 \pm 5$ for SRM612 reference glass. RhoD $=1.460 \mathrm{E}+06 \mathrm{~cm}^{-2}: \mathrm{ND}=2233$. Pooled age $=8.8 \pm 1.2 \mathrm{Ma}$. Central age $=8.9 \pm 1.3 \mathrm{Ma}$, 